\title{
Uncertainty assessment of forest road modeling with the Distributed Hydrology Soil Vegetation Model (DHSVM)
}

\author{
Christopher G. Surfleet, Arne E. Skaugset III, and Jeffrey J. McDonnell
}

\begin{abstract}
We used a generalized likelihood uncertainty estimation procedure with the Distributed Hydrology Soil Vegetation Model (DHSVM) for two streamflow and 11 road ditchflow locations. We observed considerable uncertainty in DHSVM simulations of forest road and stream runoff. The accuracy of simulations decreased as the size of the area modeled decreased. For streamflow, $44 \%$ of attempted model structures exceeded a 0.5 Nash-Sutcliffe efficiency threshold for a 630 ha catchment; $12 \%$ of attempted model structures exceeded a 0.5 Nash-Sutcliffe efficiency threshold for a 55 ha catchment. DHSVM simulations produced behavioral model structures for only six of the 11 road ditchflow sites $(<10$ ha). Cumulative distribution functions of parameter values did not indicate specific parameter ranges of parameter values across all locations, indicating that parameter values in DHSVM are influenced by their interaction with other parameters. The sensitivity of parameters and the range of that sensitivity varied across simulations of road ditchflow and streamflow. DHSVM simulations for two streamflow locations varied outside the uncertainty bounds for $10 \%-22 \%$ of storm volumes and $12 \%-22 \%$ of peak flows, respectively. Twenty-eight percent to $52 \%$ of storm volumes and $28 \%-48 \%$ of peak flows were outside the uncertainty bounds for the six road ditchflow locations.
\end{abstract}

\begin{abstract}
Résumé : Nous avons utilisé une méthode d'estimation des incertitudes «Generalized Likelihood Uncertainty Estimation» avec le modèle distribué DHSVM («Distributed Hydrology Soil Vegetation Model») pour deux sites d'écoulement fluvial et 11 sites d'écoulement en fossés de drainage en bordure de route. Nous avons observé une incertitude considérable dans les simulations du DHSVM de l'écoulement fluvial et de l'écoulement associé à un chemin forestier. La précision des simulations diminuait à mesure que la taille de la zone modélisée diminuait. Dans le cas de l'écoulement fluvial, $44 \%$ des structures de modèle testées excédaient un critère d'efficacité de Nash-Sutcliffe de 0,5 pour un bassin de 630 ha; $12 \%$ des structures de modèle testées excédaient un critère d'efficacité de Nash-Sutcliffe de 0,5 pour un bassin de 55 ha. Les simulations du DHSVM ont produit des structures de modèle comportemental pour seulement six des 11 sites d'écoulement en fossés $(<10$ ha). Les fonctions de distribution cumulative de la valeur des paramètres n'ont pas fourni d'étendues spécifiques des paramètres pour l'ensemble des sites, indiquant que la valeur des paramètres dans le DHSVM est influencée par leur interaction avec d'autres paramètres. La sensibilité des paramètres et l'étendue de cette sensibilité variaient parmi les simulations d'écoulement en fossés et d'écoulement fluvial. Dans le cas de deux sites d'écoulement fluvial, les simulations du DHSVM variaient au-delà des limites d'incertitude pour $10 \%$ à $22 \%$ des débits d'orage et $12 \%$ à $22 \%$ des débits de pointe. Dans le cas de six sites d'écoulement en fossés, $28 \%$ à $52 \%$ des débits d'orage et $28 \%$ à $48 \%$ des débits de pointe étaient à l'extérieur des limites d'incertitude.
\end{abstract}

[Traduit par la Rédaction]

\section{Introduction}

The effect of forest roads on watershed hydrology are a focus of regulatory and scientific concern. This requires that land managers and owners become more sophisticated in the assessment of the impacts of their forest roads. Forest roads generate overland flow from compacted surfaces (Harr et al. 1975; King and Tennyson 1984), intercept subsurface flow at road cuts (Burroughs et al. 1972; Megahan 1972; Wemple 1998), and alter hillslope hydrologic processes. Forest roads also can redistribute water on hillslopes and change the timing of streamflow, subsurface flow, and the distribution of soil moisture (Megahan 1972; Wigmosta and Perkins 2001), extend stream channel networks through gullies (Montgomery 1994; Wemple et al. 1996), and alter peak flows at stream crossings (Toman 2004).

The Distributed Hydrology Soil Vegetation Model (DHSVM) is a tool that can be used to assess the influence of forest roads on watershed hydrology (Wigmosta et al. 1994; Wigmosta and Perkins 2001). DHSVM contains a road interception component that models the interception of hillslope water at road cutslopes and runoff from the road surface (Storck et al. 1998; Wigmosta and Perkins 2001). Wigmosta and Perkins (2001) demonstrated the utility of the road network component of DHSVM to show changes in peak flows and in the routing of water along road net- 
works for Carnation Creek. Bowling and Lettenmaier (2001) evaluated DHSVM for 12 culverts within Hard Creek and Ware Creek and concluded that the model simulated outlet peaks well and culvert peaks approximately. Bowling and Lettenmaier (2001) predicted peak flow changes within the watershed from the road network. In addition, La Marche and Lettenmaier (2001) used DHSVM to simulate road influence on changes related to road runoff, peak flows, water table, and forest harvest within the Deschutes River watershed. Despite these studies, there are few explicit tests of the road component of DHSVM or evaluations of model uncertainty, and an equifinality assessment has not been performed.

Input requirements are demanding for physically based distributed models such as DHSVM. Inputs to the model and calculations within the model used to simulate the response can generate considerable uncertainty. Uncertainty and output error can come from a variety of sources: $(i)$ precipitation inputs greatly influence the simulations of a rainfall runoff model such as DHSVM, (ii) the measurement of precipitation has considerable spatial variability (Larson and Peck 1974; Morrissey et al. 1995) and errors are associated with its measurement (Chou 1968; Robinson and Rodda 1969; Green and Helliwell 1972; Peck 1972; Habib et al. 2001), (iii) parameter values of DHSVM (e.g., hydraulic conductivity) are represented by a single value, depending on the soil texture, although measurements of these values can vary as much as $150 \%$ (Warrick and Nielsen 1980), (iv) model structure errors account for a significant proportion of uncertainty in predictions; this uncertainty generally increases with model complexity and reflects the limitations of our understanding of the processes at work (Brazier et al. $2000)$, and (v) errors in observations of road ditchflow and streamflow used for comparison and evaluation of model output add uncertainty to comparisons of model estimates.

In this study, we performed an uncertainty analysis of DHSVM with respect to simulations of streamflow and road ditchflow. We used the generalized likelihood uncertainty estimation (GLUE) procedure (Beven and Binley 1992; Beven 2001) to evaluate the uncertainty of DHSVM simulations, parameter sensitivity, and the influence of parameter interactions.

\section{Methods}

\section{Study area}

This study was conducted in the Oak Creek watershed (630 ha) (Fig. 1) within the McDonald/Dunn Research Forest managed by the College of Forestry, Oregon State University. Elevations within the watershed range from 140 to more than $600 \mathrm{~m}$. The average annual precipitation for the Oak Creek watershed for the 2003-2006 water years was $970 \mathrm{~mm} / \mathrm{year}$ with a range of $830-1110 \mathrm{~mm} /$ year. Precipitation in the watershed is predominantly rain. The annual snowfall depth is approximately $110 \mathrm{~mm}$ (Oregon Climate Service 2005).

The underlying bedrock, the Siletz River Volcanics, is a basalt formation (Knezevich 1975). Soils in the watershed are predominately mesic Typic Hyploxerepts with areas of mesic Pachic Argixerolls and mesic Typic Palchumults. The most common soil texture is silty clay loam, although some areas with silty loam texture are present. The forest trees are predominantly Douglas-fir (Pseudotsuga menziesii (Mirb.) Franco) with minor components of other conifers, hardwood species, and grassy meadows.

There is a meteorological station near the outlet of the study watershed where continuous observations of air temperature, relative humidity, solar radiation, wind speed, and precipitation have been made since 2003. In addition, there are three rain gauges located at varying elevations and aspects throughout the watershed (Fig. 1). Hydrologic observations were recorded continuously at road ditchflow discharge locations in Oak Creek using Tru-Track capacitance rods. Discharge was calculated from stage observations based on a rating curve developed for the Oak Creek culverts (Toman 2004).

\section{DHSVM}

DHSVM is a physically based distributed hydrologic model that explicitly solves water and energy balances for each model grid cell (Bowling and Lettenmaier 2001). DHSVM was originally developed for use in forested, mountainous terrain (Wigmosta et al. 1994) and then extended for use in maritime climates (Storck et al. 1995). The model and the road interception component of the model are described in detail elsewhere (Wigmosta et al. 1994; Storck et al. 1995, 1997, 1998; Wigmosta and Perkins 2001); thus, only a brief description is provided here.

DHSVM calculates the spatial distribution of soil moisture, snow, evapotranspiration, and runoff in hourly or longer time increments for individual grid cells, or pixels, based on the digital elevation model of the watershed. Meteorological inputs required for each time increment of the model are precipitation, relative humidity, air temperature, wind speed, shortwave radiation, and longwave radiation. A one-dimensional water balance is calculated for each grid point based on effects from vegetation, climate, soil hydraulic properties, and topography. The model uses a twolayer canopy representation to calculate interception and evapotranspiration of vegetation, a two-layer energy balance model for snow accumulation and snowmelt, a multilayer unsaturated soil model based on Darcy's Law, and a saturated subsurface flow model.

Once the water balance calculations are complete, each grid cell exchanges water with adjacent grid cells, which results in a three-dimensional redistribution of surface and subsurface water across the watershed. DHSVM calculates the amount of overland flow from the road surface based on the precipitation intensity and infiltration rate of the road surface. Overland flow is routed in the road ditch to a drainage location. DHSVM also routes intercepted water at the cutslope in the road ditch to a drainage location.

\section{Site selection for study}

For the GLUE evaluation of DHSVM, we selected two streamflow locations and 11 road drainage culverts within the Oak Creek watershed for the 2003-2006 water years (Fig. 1). The two streamflow locations were the largest watershed areas with streamflow measurements: Oak Creek, at the outlet of the research watershed (630 ha), and a smaller tributary, Claire Creek (55 ha). To select the 11 road drainage sites, we used the generalized random tessel- 
Fig. 1. Upper Oak Creek watershed and study sites, Corvallis, Oregon, USA.

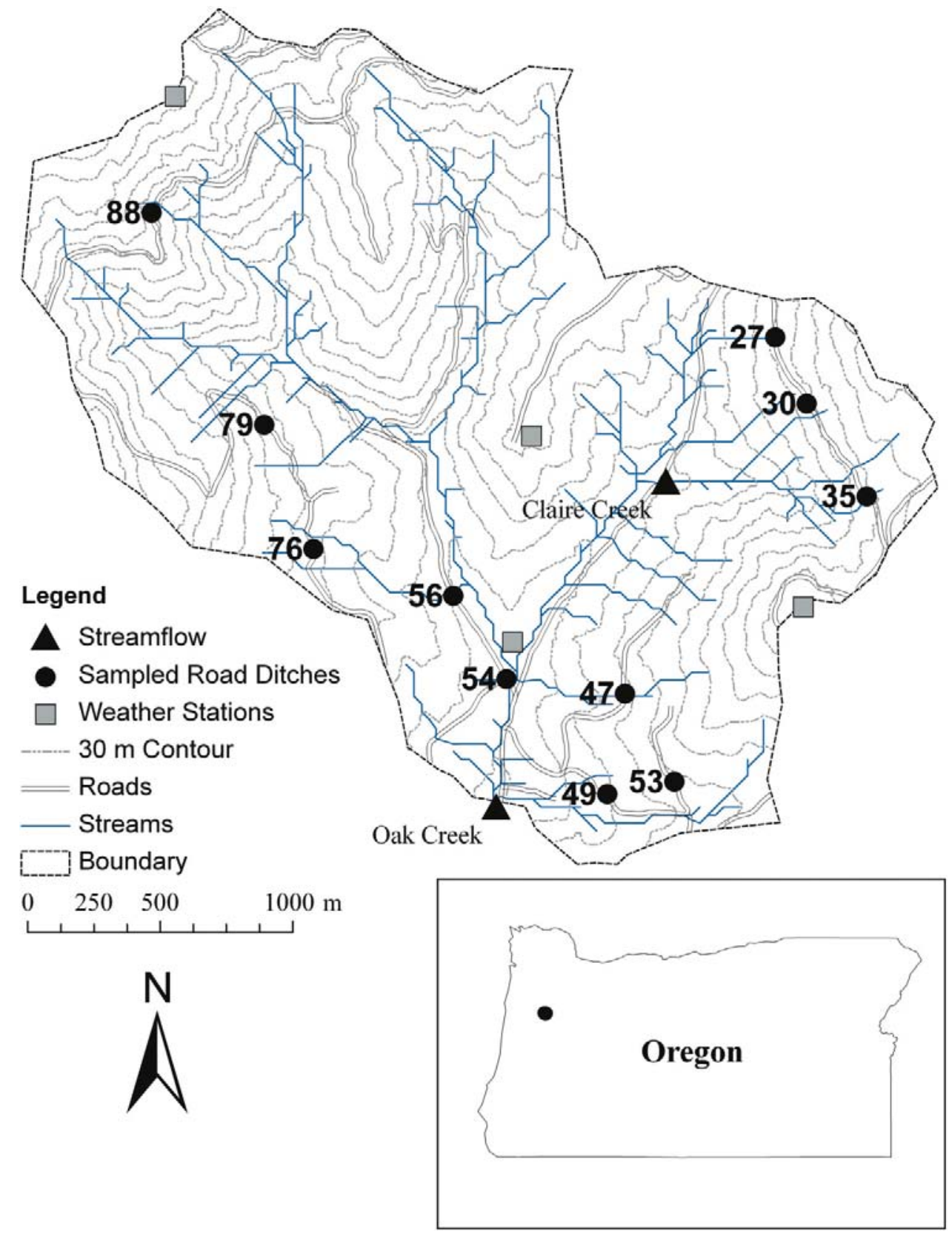

lation stratified design (Stevens and Olsen 2004), a spatially balanced sampling approach. The sampling frame comprised road sites with at least two winters of hydrologic data between the 2003 and 2006 water years.

\section{DHSVM inputs}

For input, DHSVM requires ( $i$ ) spatial information about the watershed in the form of binary grids created from ArcInfo coverages of elevation, soil type, soil depth, and vegetation type and (ii) connecting arcs (spatially aligned lines) for the stream network and road network. A $30 \mathrm{~m}$ digital elevation model for Oak Creek was projected from LIDAR data with a resolution of $6 \mathrm{~m}$. A pixel size of $30 \mathrm{~m}$ was chosen because it would be large enough to encompass the stream channel and road widths found in Oak Creek (a constraint of DHSVM).

The parameters of DHSVM that were varied for uncertainty analysis comprised physical values associated with water movement in the soil. To facilitate the Monte Carlo analysis associated with the GLUE procedure, only one soil type, a silty clay loam, was designated for Oak Creek. A vegetation layer specifying one vegetation type (coastal forest type) was used to correspond to the Douglas-fir forest of Oak Creek.

Soil depths were estimated with a soil depth model (Westrick 1999) fit to 65 field measurements of soil depth measured in Claire Creek, a tributary of Oak Creek. The soil depth model fit to field measurements provided the most ac- 
curate output for DHSVM simulations of small-area hydrologic processes, such as road runoff, compared with an average or regionally estimated soil depth (Surfleet 2008). The stream network for Oak Creek was generated by the "createstreamnetwork" Arcinfo script provided with DHSVM. The road network was mapped with GPS to within $1 \mathrm{~m}$ accuracy. Road dimensions of cutslope depth, road width, ditch width, road type (crowned, outsloped, and insloped), and road ditch depth were measured in the field. The meteorological inputs for DHSVM were taken primarily from the weather station within Oak Creek. Meteorological data from the US Bureau of Reclamation Agrimet climate station in Corvallis, Oregon, were used to develop relationships with Oak Creek meteorological data to fill missing time periods.

\section{GLUE analysis}

The initial step in the GLUE procedure was to conduct a Monte Carlo simulation with randomly selected parameter values sampled over a uniform or previously known distribution. For this study, we performed 10000 model simulations based on $(i)$ randomly selected soil values of lateral hydraulic conductivity, (ii) exponent of decay of the decrease in hydraulic conductivity by depth (an exponent of the natural logarithm describing the decrease in hydraulic conductivity by depth of soil), (iii) porosity of the soil matrix, and (iv) vertical hydraulic conductivity. These four parameters and the range of values for each parameter selected were based on preliminary model trials that demonstrated competence at achieving model fit to observed data. Table 1 shows the ranges of values randomly sampled. Because unit values for three of the parameters ranged from tenths to hundred thousandths, we used a lognormal distribution for random sampling. This method provided equal probability of sampling for both low (hundred thousandth of a unit) and high (1 or 10 units) values. Sampling from a uniform distribution would have been weighted too heavily toward high values.

\section{Likelihood function (goodness of fit)}

We used the Nash-Sutcliffe efficiency (NSE) function (Nash and Sutcliffe 1970) as the likelihood function for the GLUE procedure of DHSVM. The term "likelihood" has a broader definition for the GLUE analysis than it does in classical statistical techniques (Binley and Beven 1991). We chose the NSE, first, because it provides a reasonable test of the magnitude and timing between observed and simulated time series points and, second, because it has been successfully implemented in other GLUE analyses (e.g., McMichael et al. 2006) and used as a goodness of fit measure in other DHSVM applications (e.g., Whitaker et al. 2003).

For the GLUE procedure for Oak Creek and Claire Creek streamflow, we used DHSVM simulated time series that equaled or exceeded an NSE value of 0.5 . For road ditchflow, we used simulations that equaled or exceeded an NSE of 0.3 because the fit of the time series of road ditchflow to observed ditchflow was not as good as that for streamflow. Road runoff is highly variable and can be highly influenced by the intensity of local precipitation, which makes it difficult to match simulated and observed data by time periods. We used an NSE of 0.3 to compensate for this discrepancy and to obtain a conservative threshold value for evaluation of uncertainty in model results. Higher values of NSE with application of hydrologic modeling with DHSVM have been reported in the literature (Whitaker et al. 2003; McMichael et al. 2006). However, we used the more conservative 0.5 NSE for streamflow and 0.3 NSE for road ditchflow to ensure that behavioral model structures were not excluded because of drawbacks in the application of NSE.

\section{Sensitivity plots}

Parameter sensitivity can be interpreted from plots of the cumulative distributions of parameter values grouped according to rank by their likelihood measure. We plotted cumulative distribution functions (CDF) for lateral hydraulic conductivity, exponent of decay of hydraulic conductivity by depth, vertical hydraulic conductivity, and porosity by five different likelihood levels for each streamflow and ditchflow site with behavioral model structures simulated by DHSVM. The five levels of likelihood values represented even divisions of the range of parameter values from the lowest to the highest likelihood. The model was sensitive to a parameter if there were dissimilarities in the CDF for varying likelihood values. In contrast, similar CDFs of the varying likelihood values for a parameter indicate that the model was insensitive to that parameter.

\section{Calculation of uncertainty bounds}

The GLUE procedure allows uncertainty assessment for simulated time series. In this case, a 95\% uncertainty bound was derived from the Monte Carlo simulation. The uncertainty bounds depict prediction errors from model structure, effective parameterization, and hydrologic processes as calculated by DHSVM. The uncertainty bounds apply for the entire time series and for individual time steps. These predictive uncertainty bounds define the upper and lower prediction limits associated with the behavioral model structures; they do not represent probabilistic confidence intervals.

\section{Results}

\section{GLUE assessment of DHSVM parameters}

For the parameter ranges evaluated by the GLUE procedure, the proportion of behavioral model structures for DHSVM varied by location modeled (Table 2). For Oak Creek (630 ha), 44\% of the 10000 model structures exceeded a threshold of $0.5 \mathrm{NSE}$ and $100 \%$ exceeded 0.3 NSE. For Claire Creek (55 ha), 12\% of attempted model structures exceeded a threshold of 0.5 NSE, while $45 \%$ exceeded 0.3 NSE. DHSVM simulations exceeded the NSE criteria of 0.3 for only six of the 11 road ditchflow sites. For the six road ditchflow sites $(<10$ ha) that exceeded the minimum NSE criteria, proportions of behavioral structures that exceeded $0.3 \mathrm{NSE}$ ranged from $19 \%$ to $90 \% ; 1 \%-12 \%$ exceeded 0.5 NSE. For five road ditchflow locations, DHSVM did not produce behavioral model structures for the 10000 simulations attempted.

Parameter sensitivity and the range of that sensitivity varied by site simulated (Fig. 2). The CDF plots indicated that porosity was a sensitive parameter for all sites, except culvert 54. The spread of the CDF for varying likelihood levels for exponent of decay of the hydraulic conductivity by depth 
Table 1. Range of parameter values randomly sampled for GLUE.

\begin{tabular}{lc}
\hline Parameter & Range of values \\
\hline Lateral hydraulic conductivity $(\mathrm{m} / \mathrm{s})$ & $0.00001-1.0$ \\
Exponent of hydraulic conductivity decrease by depth & $0.01-10.0$ \\
Vertical hydraulic conductivity $(\mathrm{m} / \mathrm{s})$ & $0.00001-1.0$ \\
Porosity $(\%)$ & $40-55$ \\
\hline
\end{tabular}

Table 2. Percentage of DHSVM simulations producing behavioral model structures.

\begin{tabular}{lccl}
\hline Location & NSE $>0.5(\%)$ & NSE $>0.3(\%)$ & Type \\
\hline Oak Creek & 44 & 100 & Streamflow \\
Claire Creek & 12 & 45 & Streamflow \\
Culvert 27 & 1 & 63 & Intermittent ditchflow \\
Culvert 30 & 2 & 42 & Intermittent ditchflow \\
Culvert 54 & 12 & 90 & Intermittent ditchflow \\
Culvert 79 & 0 & 0 & Ephemeral ditchflow \\
Culvert 88 & 6 & 19 & Intermittent ditchflow \\
Culvert 35 & 0 & 0 & Intermittent ditchflow \\
Culvert 47 & 0 & 0 & Intermittent ditchflow \\
Culvert 49 & 1 & 54 & Intermittent ditchflow \\
Culvert 76 & 1 & 9 & Intermittent ditchflow \\
Culvert 53 & 0 & 0 & Intermittent ditchflow \\
Culvert 56 & 0 & 0 & Ephemeral ditchflow \\
\hline
\end{tabular}

was not as great as it was for porosity, and while it was not sensitive for all ditchflow locations, it demonstrated changes in likelihood as values of the parameter changed. The sensitivity of lateral hydraulic conductivity varied by site simulated. Lateral hydraulic conductivity was not a sensitive parameter for Claire Creek and it exhibited sensitivity for only two of the six sites at which road ditchflow was assessed with GLUE. The vertical hydraulic conductivity parameter was insensitive for all sites based on the tight grouping of CDF curves for varying likelihood levels. Vertical hydraulic conductivity did not show an association with a particular range of values based on the relatively uniform slopes of the CDFs (Fig. 2).

In general, sites that demonstrated sensitivity for one parameter showed sensitivity for the other parameters, except for vertical hydraulic conductivity, which was insensitive at all sites. At culvert 54, none of the four parameters evaluated showed sensitivity. Among the ditchflow sites, culvert 54 also had the greatest number of behavioral model structures.

The CDFs provided some indication of the range of parameter values that might be used for future simulations in Oak Creek. One interpretation was the location that showed the steepest slope on the high likelihood CDF curve (plot 5) (Fig. 2). The length of the curve with the steepest slope indicates a range of the individual parameter values with the greatest sensitivity for DHSVM simulations.

The range of the parameter values with steep sections of the $\mathrm{CDF}$ varied by site. CDF curves for lateral hydraulic conductivity had very steep slopes at the low end of the range of parameter values (Fig. 2); all but two sites show a high proportion of values of hydraulic conductivity less than $0.001 \mathrm{~m} / \mathrm{s}$ for behavioral model structures. The exponent of decay of hydraulic conductivity by depth did not show a trend of increased likelihood for particular values, although two of the sites showed the highest likelihood values for exponent of decay of hydraulic conductivity by depth between 1 and 10. Porosity did not show a distinct range of values that improved likelihood values. For a few of the sites, there was a slight indication that porosity greater than 0.5 might provide higher likelihood values, but this was not true for all sites, nor was the evidence conclusive.

\section{Uncertainty bounds for DHSVM simulations}

Figures 3 and 4 show the $95 \%$ uncertainty bounds for the two streamflow and two representative road ditchflow sites that produced behavioral model structures from DHSVM simulations in Oak Creek. DHSVM simulations for the outlet of Oak Creek had less uncertainty than the other sites evaluated. Storm volumes and peak flows were generally within the uncertainty bounds derived from the GLUE procedure (Fig. 3). Only $10 \%$ of storm volumes and $12 \%$ of peak flows observed were outside the uncertainty bounds (Table 3). The accuracy of DHSVM simulations decreased as the size of the area modeled decreased. Oak Creek was the largest area modeled (630 ha), and DHSVM output had less uncertainty, based on percentages of storm volumes and peak flows outside the uncertainty bounds. DHSVM simulations for Claire Creek (55 ha) showed greater uncertainty; $22 \%$ of storm volumes and $22 \%$ of peak flows were outside the uncertainty bounds (Fig. 3; Table 3). For the six road ditchflow locations analyzed with GLUE, $28 \%-52 \%$ of storm volumes and $28 \%-48 \%$ of peak flows were outside the uncertainty bounds (Table 3; Fig. 4).

Five road ditchflow locations did not meet the criteria for model fit, demonstrating high uncertainty of model results related to road ditchflow location. Figure 5 shows one DHSVM model structure calibrated to Oak Creek and Claire Creek streamflow for two of these road ditchflow locations to demonstrate the problems in DHSVM simulations. During 
Fig. 2. Sensitivity for four soil hydraulic parameters of DHSVM expressed as cumulative distributions in five levels of likelihood values for behavioral model simulations from lowest likelihood values (plot 1) to highest likelihood values (plot 5).

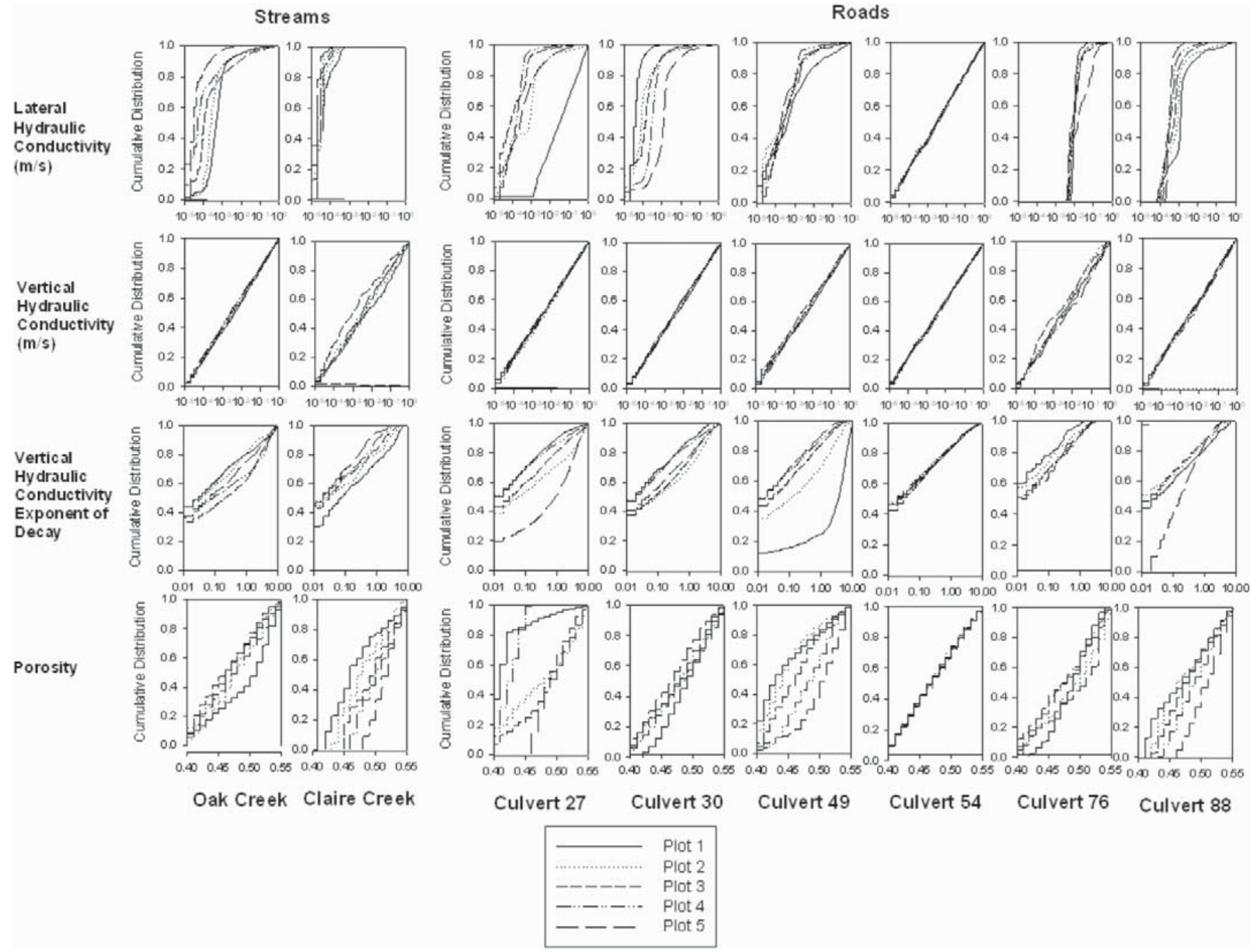

the time period modeled for Oak Creek (2003-2006), four storms had a recurrence interval greater than 1 year: the largest four storms during the 2006 water year. These four storms are shown at the right side of each of the time series graphs (Figs. 3, 4, and 5). Estimations of storm volume for these events varied considerably (Table 3 ). Storm volumes observed for the largest areas modeled, Oak Creek and Claire Creek, were within the uncertainty bounds for these four largest storms. At road ditchflow sites, storms with recurrence intervals greater than 1 year varied between zero and three storms within uncertainty bounds. At Oak Creek, one of the 1-year recurrence peak flows was outside the uncertainty bounds; at Claire Creek, however, three of the 1year recurrence peak flows were outside the uncertainty bounds. At the road ditchflow sites, peak flows varied from 0 to 4 within the uncertainty bounds. This result demonstrates wide variability in the fit of DHSVM results within uncertainty bounds for large events. The trend observed for simulations at the largest area modeled (Oak Creek) showed better fit to storms with recurrence intervals greater than 1 year than did the small-area simulations (road ditches).

Figure 6 shows storm volumes for streamflow and their subsequent uncertainty bounds for Oak Creek and Claire Creek. Figure 7 provides the same information for the two road ditchflow locations with DHSVM behavioral model structures. The trend shows small storm volumes at the lower end of the uncertainty bounds and large storms at the middle to upper ends of the uncertainty bounds, often outside the uncertainty bounds. These results suggest that DHSVM tended to overpredict the volume of small storms. In contrast, DHSVM often underpredicted the large storm volumes and peak flows (events with recurrence intervals greater than a 1 year) for the ditchflow locations. Similar results for Claire Creek showed that DHSVM underpredicted peak flows with recurrence intervals greater than 1 year (Table 3).

\section{Discussion}

DHSVM is a tool to assess the influence of forest roads influences on watershed hydrology. To date, only manual calibration techniques, the systematic altering of the most sensitive or influential parameters of the model through a sequence of model runs, have been used with DHSVM. The 
Fig. 3. Uncertainty bounds for DHSVM results for Oak Creek (630 ha) and Claire Creek (55 ha) compared with observed winter streamflow, 2003-2006. The $x$-axis time steps represent $3 \mathrm{~h}$ intervals; the $y$-axis streamflow represents cubic metres per $3 \mathrm{~h}$. The time series in the plots do not correspond to each other due to varying lengths of records; no comparison of timing among plots can be made.

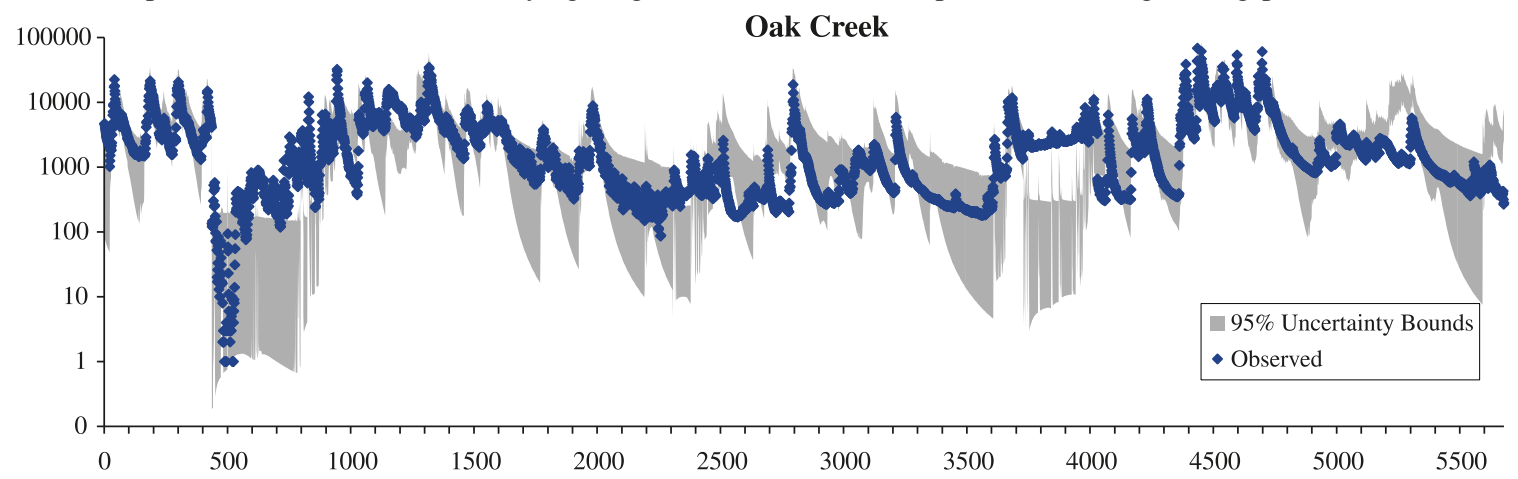

Claire Creek

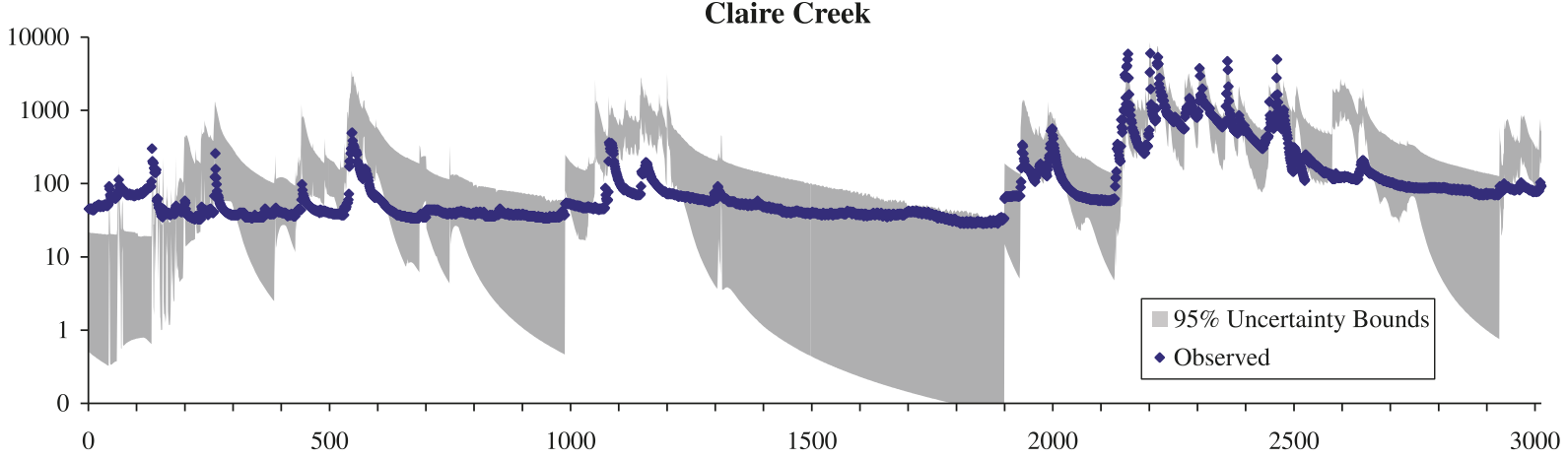

Fig. 4. Uncertainty bounds for DHSVM results for two road locations with behavioral model structures compared with observed winter streamflow, 2003-2006. The $x$-axis time steps represent $3 \mathrm{~h}$ intervals; the $y$-axis streamflow represents cubic metres per $3 \mathrm{~h}$. The time series in the plots do not correspond to each other due to varying lengths of records; no comparison of timing among plots can be made.

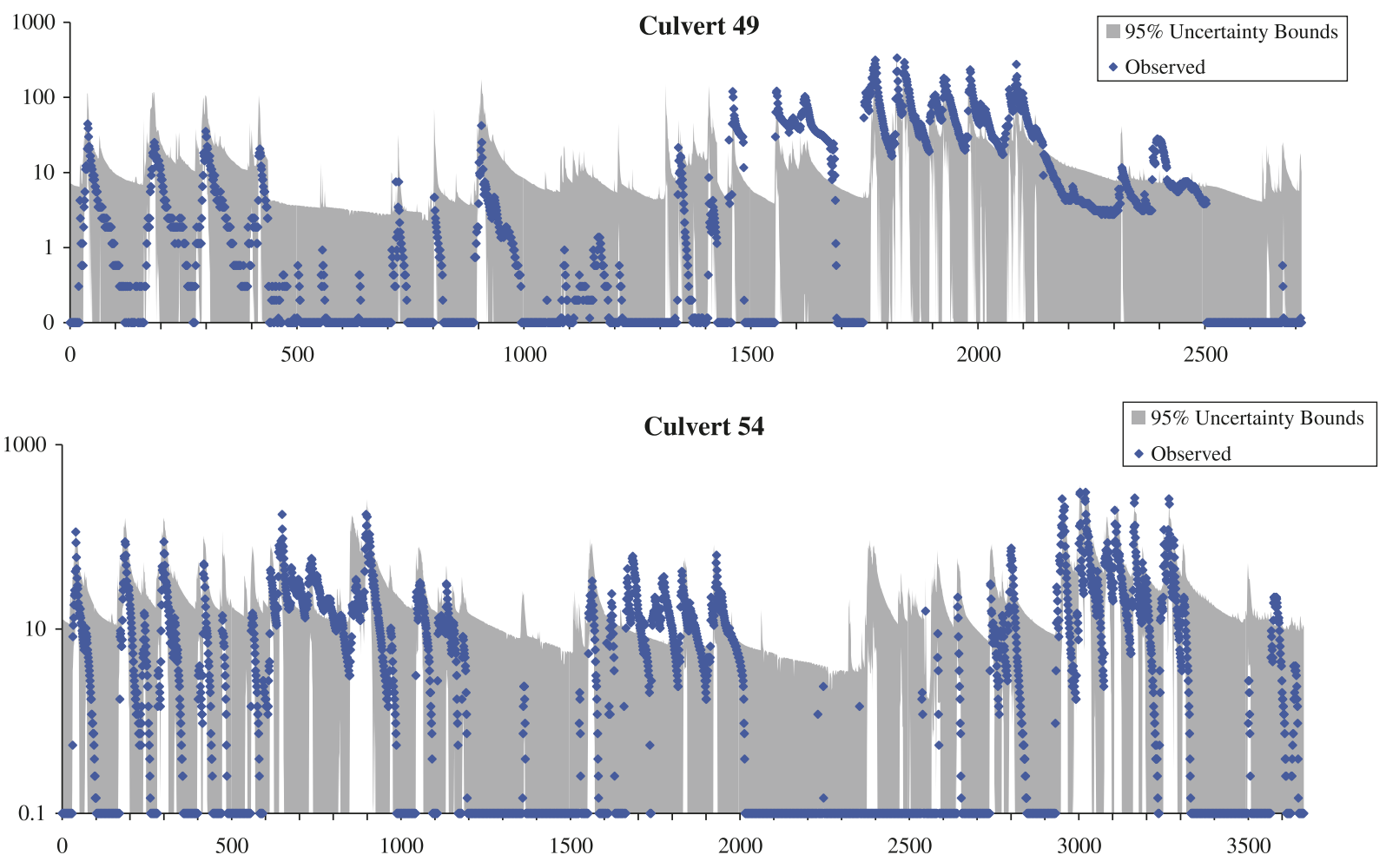


Table 3. Percentage of observed storm events outside the DHSVM 95\% uncertainty bounds.

\begin{tabular}{llllr}
\hline & $\begin{array}{l}\text { \% storm volume } \\
\text { outside uncertainty } \\
\text { bounds }\end{array}$ & $\begin{array}{l}\text { \% storm peak flows } \\
\text { outside uncertainty } \\
\text { bounds }\end{array}$ & $\begin{array}{l}\text { \% storm volumes }>1 \text {-year } \\
\text { event outside uncertainty } \\
\text { bounds }\end{array}$ & $\begin{array}{l}\text { \% storm peak flows }>1 \text {-year } \\
\text { event outside uncertainty } \\
\text { bounds }\end{array}$ \\
\hline Oak Creek & 10 & 12 & 0 & 25 \\
Claire Creek & 25 & 22 & 0 & 75 \\
Culvert 27 & 30 & 30 & 75 & 0 \\
Culvert 30 & 33 & 28 & 50 & 50 \\
Culvert 49 & 50 & 48 & 75 & 100 \\
Culvert 54 & 14 & 38 & 0 & 75 \\
Culvert 76 & 36 & 46 & 0 & 75 \\
Culvert 88 & 30 & 33 & 0 & 0 \\
Mean & 29 & 32 & 25 & 50 \\
\hline
\end{tabular}

Fig. 5. DHSVM simulation for two road locations with no behavioral model structures compared with observed winter streamflow, 20032006. The $x$-axis time steps represent $3 \mathrm{~h}$ intervals; the $y$-axis streamflow represents cubic metres per $3 \mathrm{~h}$. The time series in the plots do not correspond to each other due to varying lengths of records; no comparison of timing among plots can be made.
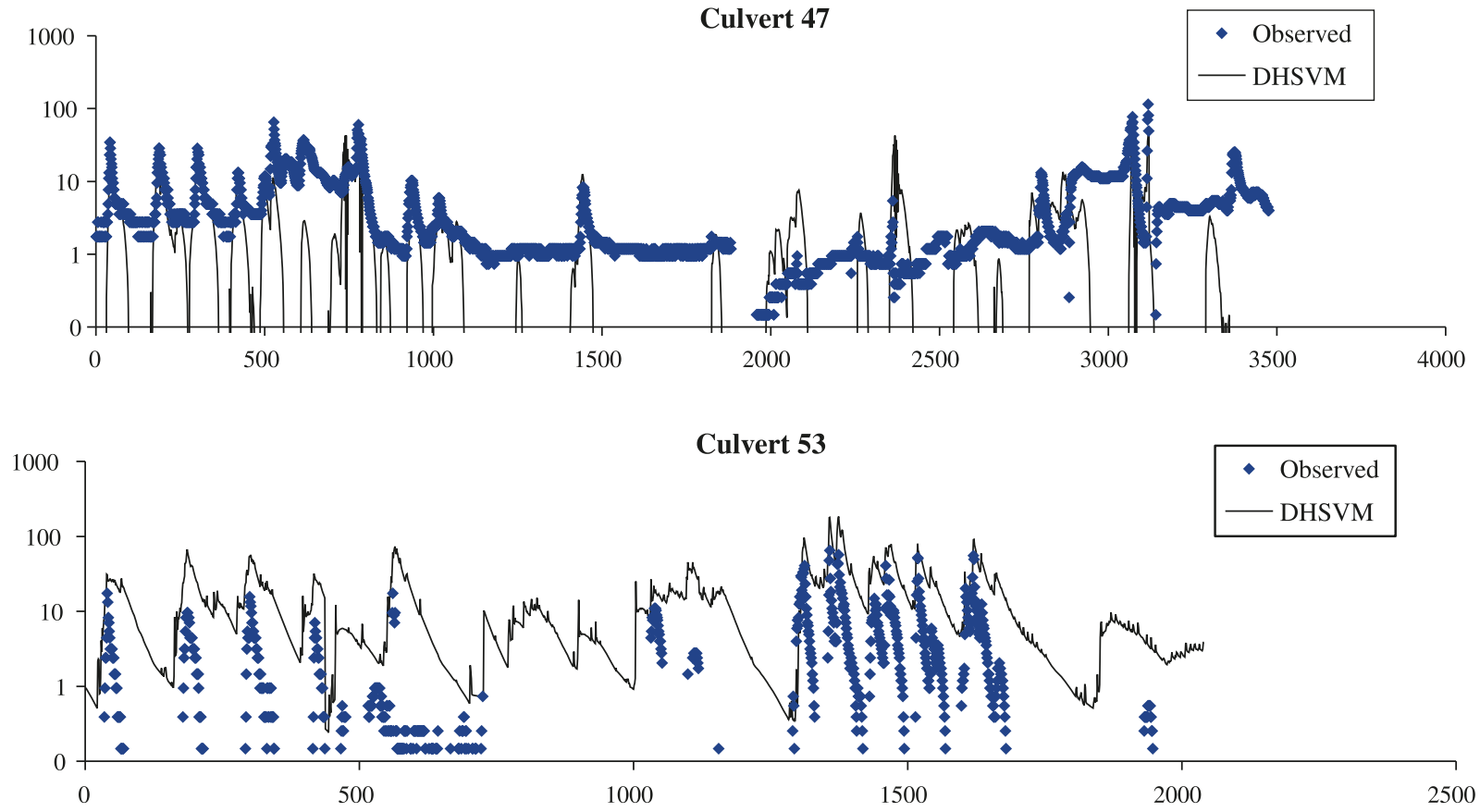

problem with this approach is that it does not address the concept of equifinality in the model's use, which means that many different model structures or groups of parameters can provide acceptable answers. It would be preferable to present model results in a range of acceptable answers to demonstrate the uncertainty in the model output. To date, the use of DHSVM to model road hydrologic effects has relied on one set of calibrated model parameters for its predictions (Bowling and Lettenmaier 2001; La Marche and Lettenmaier 2001; Wigmosta and Perkins 2001; Cuo et al. 2003). All published accounts of DHSVM hydrologic simulations have relied on calibration of the model to one model structure (e.g., Leung and Wigmosta 1999; Whitaker et al. 2003; Beckers and Alila 2004; Schnorbus and Alila 2004). Our results demonstrated considerable uncertainty in the use of DHSVM to represent forest road runoff; this suggests problems with a one-model structure approach.

\section{Uncertainty and area}

The area simulated by DHSVM influenced the uncertainty of model results. The largest area where streamflow was simulated was the outlet of Oak Creek (630 ha). Oak Creek produced the highest proportion of behavioral model structures from the GLUE analysis. Oak Creek simulations also provided the greatest proportion of modeled storm runoff volumes and peak flows within uncertainty bounds. Claire Creek produced the second highest amount of behavioral model structures, the second largest proportion of peak flows, and the third largest proportion of storm volumes within uncertainty bounds. The smallest watershed areas modeled, the road ditchflow locations, produced low proportions of behavioral model structures and low proportions of storm volumes and peak flows within uncertainty bounds. For several of the road ditchflow locations, no behavioral model structures were identified. 
Fig. 6. Observed storm volumes and DHSVM uncertainty bounds for Oak Creek and Claire Creek. Storm volumes are plotted in increasing volume. The storm numbers are not the same storms for each plot due to the varied length of records.

Oak Creek

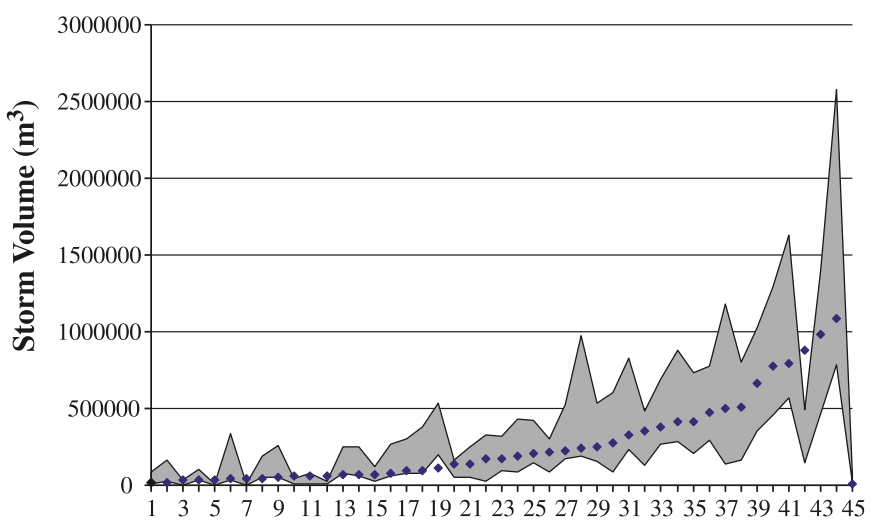

Storms

Claire Creek

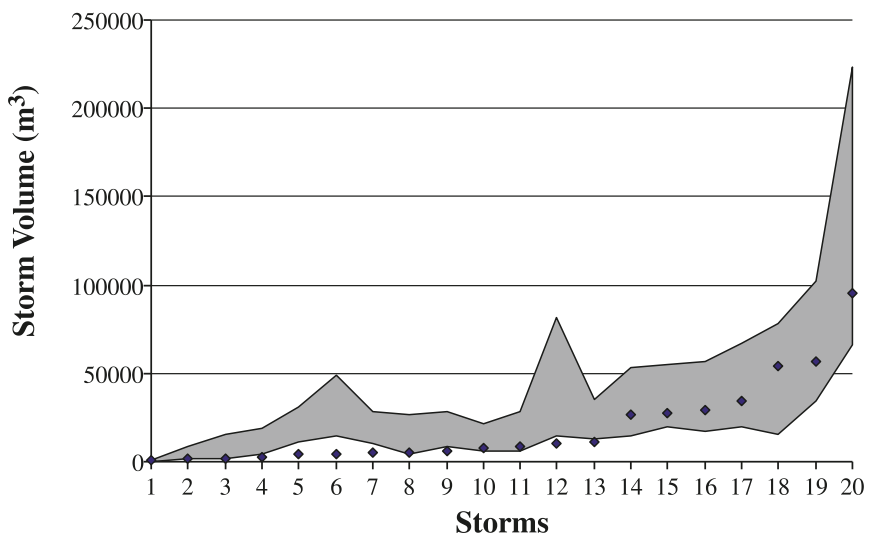

The ability of DHSVM to simulate hydrologic responses diminished for smaller catchment areas where the soil matrix and associated hydrologic processes can be highly varied. A limited number of model parameter combinations were able to simulate the runoff within this variability. This could be explained by a lack of site-specific data with which the parameters of the model could be adjusted, although it is more likely that the conceptualization of the hydrologic processes in DHSVM are better suited for capturing larger catchment area responses. Many of the associations between DHSVM parameters are nonlinear; this would have a greater effect on modeling smaller areas where parameter accuracy would be most important. Small-scale soil, vegetation, and climate differences have greater influence on modeling runoff in small catchment areas than in large ones. In large catchments, greater generalization of the soil and hydrologic processes is more likely to meet modeling objectives.

The number of behavioral model structures decreased with a decrease in area modeled (Table 3). This relationship demonstrates that a greater number of model structures can produce reasonable outcomes as the area of the watershed modeled increases. Because our results show that the outlet of a watershed accepts a larger number of model structures, it is likely that model structures that are behavioral for smaller areas will produce behavioral model structures for
Fig. 7. Observed storm volumes and DHSVM uncertainty bounds for two road locations with behavioral model structures. Storm volumes are plotted in increasing volume. The storm numbers are not the same storms for each plot due to the varied length of records.

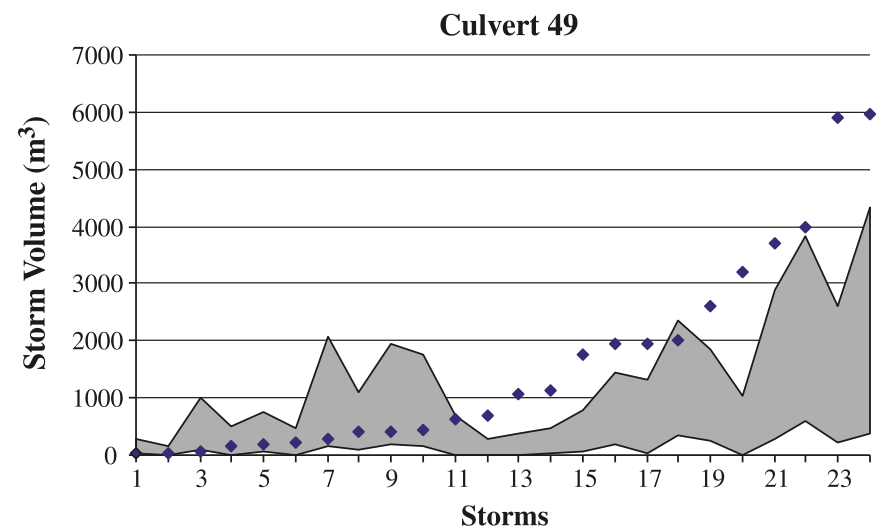

Culvert 54

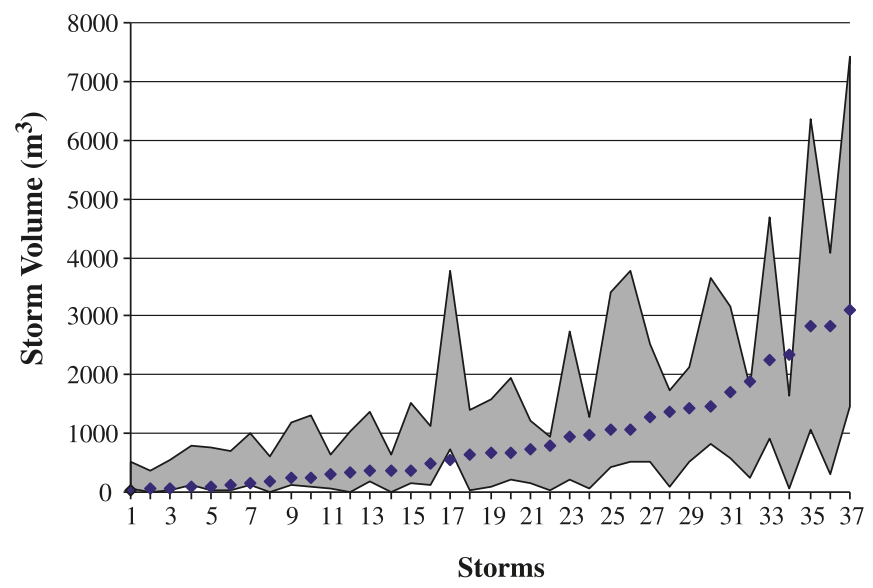

larger areas. Thus, model structures chosen for DHSVM might be improved with internal watershed data at smaller scales than the outlet of the watershed to be researched. Using internal watershed information for model calibration is counter to what many modelers actually do; models are calibrated by fit to the streamflow at the watershed outlet, with some validation to internal watershed data. Most streamflow observations available to evaluate models are at larger watershed areas. The results here suggest that greater consideration should be placed on collecting and adjusting models from smaller area observations. Certainly this is the point of using distributed hydrologic models: to have greater control of the model calculations for small-scale processes.

\section{Parameter values of DHSVM and uncertainty}

A limitation of the GLUE assessment is its dependence on Monte Carlo simulation (Beven 1998). For complex models that require much computer time for a single run, such as DHSVM, it is not possible to fully explore all parameter interactions. Our analysis was limited by the computer resources available, which resulted in only 10000 simulations that varied only four model parameters. However, it has been suggested that the upper limit of model performance is often well defined by a limited number of model realizations (e.g., thousands) and that prediction intervals are reasonable in 
comparison with larger numbers of realizations (e.g., millions) (Beven 1998).

Generally, parameter values that produced higher likelihood values also produced model structures with low likelihood values. This indicates that the parameter values manipulated in the GLUE procedure are influenced by their interactions with each other. The GLUE procedure showed that no optimum model structure could accurately estimate the runoff for all road and streamflow sites across Oak Creek. Different parameter value ranges and interaction of parameters suggest that equifinality, the ability or likelihood of many model structures to estimate the observed data, would be an appropriate approach for DHSVM evaluations.

Lateral hydraulic conductivity and porosity and the exponent of decay of hydraulic conductivity by depth were sensitive model parameters for producing behavioral model structures for DHSVM. But lateral hydraulic conductivity was not sensitive for all sites. This was surprising, as this parameter is considered influential in calculating subsurface hydrologic response. Technical support for DHSVM suggests the use of this parameter, among others, to assist in calibrating the model (Land Surface Hydrology Research Group 2008). However, the results from the GLUE assessment showed that, although setting the lateral hydraulic conductivity at a value reasonable for the various soil types is important, making many adjustments to this parameter to improve model fit might not be successful. The interaction among parameter values appears to be more important for model fit.

Soil porosity directly influences the volume of subsurface water calculated for each grid cell of DHSVM; increased porosity indicates a higher volume of soil available for water storage when all other soil attributes are constant. The same relationship is true with increases in soil depth; thus, porosity could be viewed as a surrogate for soil depth in model calculations, provided other model parameters affected by soil are similar. The varying ranges of porosity observed from the GLUE analysis therefore might be attributed to inaccurate soil depth values upslope from road culvert locations. Within the Monte Carlo simulations, the porosity value is held constant across the watershed for each simulation, yet observed hydrologic data suggest that results varied spatially. In previous research, we found soil depth to be influential in improving DHSVM results (Surfleet 2008). Soil depth varies spatially, yet was not well estimated by topography or physical terrain attributes. The sensitivity of soil porosity suggests that spatial manipulation of porosity could improve DHSVM results for small-scale modeling.

\section{Inaccuracy of DHSVM simulated road responses at Oak Creek}

The hydrologic response of roads at Oak Creek was highly variable, as observed from data for the roads for which DHSVM did not produce behavioral model structures (Fig. 5). For roads in the Oak Creek watershed, ditchflow varied from intermittent (flows all winter, culvert 47) (Fig. 5) to ephemeral (flows only when raining, culverts 53) (Fig. 5). Other roads exhibited a mix of intermittent and ephemeral road responses that depend on winter precipitation conditions. Still other roads exhibited little to no ditchflow, even with a connected road cutslope and tread. The varied hydrologic responses from roads in Oak Creek suggest that there is considerable uncertainty associated with the conceptual model of road interception and surface runoff, used in DHSVM, for predicting road hydrologic effects.

Attempts to use physical measurements of topography, soils, and road prisms to predict a road's hydrologic response have met with mixed success. Wemple and Jones (2003) reported that hillslope length, soil depth, and cutslope height explained much of the variability in the amount of subsurface flow intercepted by cutslopes at the H.J. Andrews Experimental Forest in the western Cascades. La Marche and Lettenmaier (2001) found no relationship between peak runoff and cutslope height of adjoining road segments in the Deschutes River watershed in Washington. Gilbert (2002) found no relationship between spatial variability of subsurface water interception from roads and topographic indicators in the Oregon Coast Range. Ellingson (2002) found that road length and elevation (surrogate for orographic precipitation effects) weakly correlated with the peak discharge from roads for one storm analyzed in the Oak Creek watershed in the Oregon Coast Range. However, no relationship was found for topographic or physical properties and total storm runoff volume from roads. In a study of the Deschutes River in Washington, La Marche and Lettenmaier (2001) found that neither road gradient nor road drainage area was statistically significant in determining the occurrence of gullies from road drainage. This result might indicate that the presence of macropore or pipe flow was more important than hillslope steepness in determining the amount of subsurface flow intercepted by a road segment and hence the propensity for gullies to form below the culverts (La Marche and Lettenmaier 2001).

In the conceptual model within DHSVM for road hydrologic effect, interception of hillslope water occurs when a seasonally high water table flowing over an impermeable base (e.g., bedrock) becomes deep enough to intersect the road ditch. The fraction of the permeable soil occupied by the road cut becomes a controlling factor in the amount of interception of subsurface flow. The published record on the interception of hillslope water by roads demonstrates the complexity of the subject and suggests substantial variability (Luce 2002). Various researchers have observed that cutslope contributions can be much smaller than, equal to, or much greater than road surface contributions; the dependencies are not clear (Luce 2002). In several studies on forest roads in Idaho and Oregon, researchers found that a substantial part of the road runoff came from subsurface flow intercepted by the cutslope (Burroughs et al. 1972; Megahan 1972; Wemple 1998; Marbet 2003). Marbet (2003) and Toman (2004) found that in watersheds in the Oregon Coast Range, the dominant mechanism for road runoff was variable throughout the watersheds. For some road segments, the dominant mechanism was road interception of hillslope water, whereas for others, it was overland flow from the road tread.

Despite a reasonable effort to measure soil depth in the field and a variety of different attempts at spatial extrapolation, we did not achieve an accurate spatial representation of the soil depths in Oak Creek (Surfleet 2008). Variable weathering and fractures within the basalt geology in Oak Creek have created topography at the bedrock surface that 
is highly erratic and does not reflect the shape of the surface topography. The soil depths were poorly predicted by the physical characteristics used in the soil depth model (Westrick 1999) provided with DHSVM (Surfleet 2008). Because DHSVM is a fully distributed model, it might be possible to find parameter sets that provide a better fit to individual road cuts and hillslopes, but their use would increase the complexity of the modeling exercise, perhaps beyond the scope of most decision-based analysis.

La Marche and Lettenmaier (2001) observed similar uncertainty in road hydrologic response by DHSVM in an application in the Deschutes River, Washington. They hypothesized that this uncertainty could result from ditch infiltration, which is observed in the field but not modeled in DHSVM. They also noted that road surface runoff is only crudely represented in DHSVM. For roads, most hydrologic effects modeled by DHSVM represent interception of hillslope water at the cutslope. In case studies of groundwater effects from roads in Alaska, Kahklen and Moll (1999) observed that groundwater intercepted by road cuts was quickly infiltrated into the porous road ditch. They suggested that some road prisms might act like conduits drawing hillslope water under the road. DHSVM assumes that the bedrock below the soil is impervious. Although not measured, certainly some water leakage occurs into the fractured volcanic rocks in this watershed. Interception of hillslope water was not consistent for some of the roads in Oak Creek, which created an overprediction of road runoff.

\section{Implications for management and change detection}

Considerable uncertainty was identified in road hydrologic modeling by DHSVM for Oak Creek. The results suggest that using DHSVM as a change detection tool in a watershed such as Oak Creek, with highly variable hillslope water flow and road interception, must be approached carefully. For watersheds such as Oak Creek, it would be difficult to conclusively determine hydrologic change using the approach of one model structure calibrated to the watershed, the approach used in other studies (Bowling and Lettenmaier 2001; La Marche and Lettenmaier 2001).

The fact that many road runoff locations analyzed in Oak Creek produced behavioral model structures suggests that individual road locations could be assessed for hydrologic change within an equifinality approach. Behavioral model structures identified for the individual road runoff locations could be simulated in DHSVM with the road removed. The difference in simulated road runoff with and without the roads for all of the behavioral model structures would provide a range of road hydrologic changes that could be interpreted from DHSVM. Likewise, this same approach could be done at larger watershed areas where behavioral model structures identified at streamflow locations could be modeled in DHSVM with the roads removed, which would provide a range of hydrologic change from the roads. The assumption that must be accepted is that the behavioral model structure identified with roads in the watershed would still be behavioral when the roads are removed.

Several of the road runoff locations for Oak Creek had no behavioral model structures with DHSVM. For these sites, DHSVM cannot be used as a change detection tool. Therefore, the modeler is limited in change detection assessment to sites for which behavioral model structures can be produced. The question becomes what would this mean to the assessment of change detection of road hydrologic effects at the watershed scale? If not all road runoff locations provide behavioral model structures in a watershed, can a watershedscale assessment of change detection of roads be trusted? We suggest that the answer depends on how well DHSVM does overall in the watershed; however, in their analyses of change detection, modelers should provide the shortcomings and uncertainties of their modeling efforts so that any conclusions can be interpreted accordingly.

The uncertainty in simulations was highest for individual road ditchflow locations in Oak Creek and in the smaller streamflow location at Claire Creek. Uncertainty decreased for the simulations of streamflow at the outlet of Oak Creek. It appears reasonable to approach a change detection assessment for road effects modeled by DHSVM at the watershed scale of Oak Creek but not at smaller tributaries in the watershed, such as Claire Creek. However, an equifinality approach produced a wide range of answers. Thus, only a substantial hydrologic change could be conclusively interpreted.

Because behavioral model structures were not observed for several of the road sites simulated, a modeling approach based strictly on physical characteristics of topography, soil, vegetation, and road dimensions for watershed scale change detection with DHSVM is difficult. This might be addressed through a more probabilistic approach to determining parameter values. The GLUE analysis provided distributions of parameter values that produced behavioral model structures with higher likelihood values for specific spatial locations. If enough simulations were conducted, and the observations were balanced across a watershed, the resulting trends observed could adjust parameter values across space as required. This strategy would entail using geostatistical techniques for spatial interpolation of parameter values. It would eliminate the ability to assess individual road segments, but it might reduce uncertainty for regions of the watershed, such as individual tributaries.

\section{Conclusions}

The GLUE procedure provided useful information toward equifinality of DHSVM results. The creation of uncertainty bounds based on several influential parameter sets demonstrated the wide range of acceptable results for road hydrologic modeling achievable with DHSVM. Results showed the influence of interacting parameter values, and some a priori parameter ranges can be interpreted for future DHSVM applications. Likewise, knowledge of the sensitivity of parameters such as porosity and, to a lesser extent, the exponent of decay of hydraulic conductivity by depth and lateral hydraulic conductivity can assist future use of DHSVM. The fact that so many repetitions of DHSVM were used is in itself an argument for using the GLUE procedure with DHSVM.

We observed considerable uncertainty in DHSVM estimates of road hydrologic response at Oak Creek. The variable responses of subsurface water, complex soil development, and complex soil-water interactions within Oak Creek appear to be the reasons for so much uncertainty in DHSVM results. As the area increased, the uncertainty in 
DHSVM results decreased. Streamflow observations at the outlet of Oak Creek showed less uncertainty and provided the most diverse range of behavioral model structures. Because our results showed that the outlet of a watershed accepts a larger variety of model structures, model structures that accurately estimate hydrologic responses at small scales are more likely to produce behavioral model structures at large scales. This suggests that the use of internal watershed data, at scales smaller than the outlet of the watershed to be researched, to determine model structures would improve the use of DHSVM or other hydrologic models.

Our research incorporating diverse model structures into DHSVM made the GLUE procedure useful for interpreting DHSVM results. DHSVM did not produce behavioral model structures for all roads evaluated, important when the use of DHSVM as a change detection tool is considered. It suggests that change detection will be limited to sites or sizes of watershed for which behavioral model structures can be identified. An alternative approach could be to identify parameter values that were most effective to produce behavioral model structures for varied spatial locations. These parameter ranges could then be varied across the watershed. This approach might reduce uncertainty in watershed scale change detection analysis but would eliminate the ability to evaluate individual roads in a watershed.

\section{Acknowledgements}

This work was made possible by grants from the National Council of Air and Stream Improvement, Fish and Wildlife Habitat in Managed Forests Research Program, College of Forestry, Oregon State University, and Center for Wood Utilization Grant, Department of Forest Engineering, Oregon State University. The L.L. Stewart Graduate Fellowship provided financial support for Christopher Surfleet.

\section{References}

Beckers, L., and Alila, Y. 2004. A model of rapid preferential hillslope runoff contributions to peak flow generation in a temperate rain forest watershed. Water Resour. Res. 40(3): W03501. doi:10.1029/2003WR002582.

Beven, K.J. 1998. Generalized likelihood uncertainty estimation. Document accompanying the GLUE teaching package [online]. Available from www.es.lancs.ac.uk/hfdg/freeware/ hfdg_freeware_glue.htm [accessed January 2008].

Beven, K.J. 2001. Rainfall-Runoff modeling - the primer. Wiley, Chichester, U.K.

Beven, K.J., and Binley, A.M. 1992. The future of distributed models: model calibration and uncertainty prediction. Hydrol. Process. 6(3): 279-298. doi:10.1002/hyp.3360060305.

Binley, A.M., and Beven, K.J. 1991. Physically based modeling of catchment hydrology: a likelihood approach to reducing predictive uncertainty. In Computer modeling in the environmental sciences. Edited by D.G. Farmer and M.J. Rycroft. Clarendon Press, Oxford, U.K. pp. 75-88.

Bowling, L., and Lettenmaier, D. 2001. The effects of forest roads and harvest catchment hydrology in a mountainous maritime environment. In Land-use and watersheds: human influence on hydrology and geomorphology in urban and forest areas. Water and Science Application. Vol. 2. Edited by American Geophysical Union. American Geophysical Union, Washington, D.C. pp. 145-164.

Brazier, R., Beven, K., Freer, J., and Rowan, J. 2000. Equifinality and uncertainty in physically based soil erosion models: application of the GLUE methodology to WEPP - the Water Erosion Prediction Project - for sites in the UK and USA. Earth Surf. Process. Landf. 25(8): 825-845. doi:10.1002/10969837(200008)25:8<825::AID-ESP101>3.0.CO;2-3.

Burroughs, E.R., Jr., Marsden, M.A., and Haupt, H.F. 1972. Volume of snowmelt intercepted by logging roads. J. Irrig. Drain. Div. 98: $1-12$.

Chou, K.C. 1968. Research and discussion on definite precipitation measurement. Sci. Rep. 5. Departments of Geography and Meteorology, National Taiwan University, Tai-Pei, Formosa. pp. 48-65.

Cuo, L., Giambelluca, T.W., Ziegler, A.D., and Nullet, M.A. 2003. Using distributed-hydrology-vegetation model to study road effects on stream flow and soil moisture. Eos Trans. AGU, 84(46). Fall Meeting Suppl., Abstract H51A-07.

Ellingson, K. 2002. Road surface runoff for the Oak Creek watershed: the influence of hillslope and road characteristics. Master of Forestry project, Oregon State University, Corvallis, Ore.

Gilbert, E.H. 2002. A characterization of road hydrology in the Oregon Coast Range. M.Sc. thesis, Oregon State University, Corvallis, Ore.

Green, M.J., and Helliwell, P.R. 1972. The effect of wind on the rainfall catch report. Water Research Association, Medmenham, Marlow, Buckinghamshire, U.K. pp. 1-7.

Habib, E., Krajewski, W.F., and Kruger, A. 2001. Sampling errors of tipping-bucket rain gauge measurements. J. Hydrol. Eng. 6(2): 159-166. doi:10.1061/(ASCE)1084-0699(2001)6:2(159).

Harr, R.D., Harper, W.C., Krygier, J.T., and Hsieh, F.S. 1975. Changes in storm hydrographs after road building and clear-cutting in the Oregon Coast Range. Water Resour. Res. 11(3): 436444. doi:10.1029/WR011i003p00436.

Kahklen, K., and Moll, J. 1999. Measuring effects of roads on groundwater: five case studies. U.S. Department of Agriculture, Forest Service, Technology and Development Program, San Dimas, Calif. Available from www.stream.fs.fed.us/water-road/ w-r-pdf/groudwatercases.pdf [accessed 1 March 2010].

King, J.G., and Tennyson, L.C. 1984. Alteration of streamflow characteristics following road construction in north central Idaho. Water Resour. Res. 20(8): 1159-1163. doi:10.1029/ WR020i008p01159.

Knezevich, C.A. 1975. Soil survey of Benton County area, Oregon. U.S. Department of Agriculture, Soil Conservation Service, in cooperation with the Oregon Agricultural Experiment Station. Available from www.or.nrcs.usda.gov/pnw_soil/or_data.html [accessed 19 May 2010].

La Marche, J., and Lettenmaier, D. 2001. Effects of forest roads on flood flows in the Deschutes River, Washington. Earth Surf. Process. Landf. 26(2): 115-134. doi:10.1002/10969837(200102)26:2<115::AID-ESP166>3.0.CO;2-O.

Land Surface Hydrology Research Group. 2008. Web site for the Distributed Hydrology Soil Vegetation Model. Available from www.hydro.washington.edu/Lettenmaier/Models/DHSVM [accessed 25 March 2008].

Larson, L., and Peck, E. 1974. Accuracy of precipitation measurements for hydrologic modeling. Water Resour. Res. 10(4): 857863. doi:10.1029/WR010i004p00857.

Leung, L.R., and Wigmosta, M.S. 1999. Potential climate change impacts on mountain watersheds in the Pacific Northwest. J. Am. Water Resour. Assoc. 35(6): 1463-1471. doi:10.1111/j. 1752-1688.1999.tb04230.x.

Luce, C. 2002. Hydrological processes and pathways affected by forest roads: what do we still need to learn? Hydrol. Process. 16(14): 2901-2904. doi:10.1002/hyp.5061. 
Marbet, E. 2003. Hydrology of five forest roads in the Oregon Coast Range. M.Sc. thesis, Oregon State University, Corvallis, Ore.

McMichael, C., Hope, A., and Loaiciga, H. 2006. Distributed hydrologic modeling in California semi-arid shrublands: MIKE SHE model calibration and uncertainty estimation. J. Hydrol. (Amst.), 317(3-4): 307-324. doi:10.1016/j.jhydrol.2005.05.023.

Megahan, W. 1972. Subsurface flow interception by a logging road in mountains of central Idaho. In Proceedings of the National Symposium on Watersheds in Transition. American Water Resources Association, Fort Collins, Co. pp. 350-356.

Montgomery, D.R. 1994. Road surface drainage, channel initiation and slope instability. Water Resour. Res. 30(6): 1925-1932. doi:10.1029/94WR00538.

Morrissey, M.L., Maliekal, J.A., Greene, J.S., and Wang, J. 1995. The uncertainty of simple spatial averages using rain gauge networks. Water Resour. Res. 31(8): 2011-2017. doi:10.1029/ 95WR01232.

Nash, J., and Sutcliffe, J. 1970. River flow forecasting through conceptual models. Part I - a discussion of principles. J. Hydrol. (Amst.), 10(3): 282-290. doi:10.1016/0022-1694(70)90255-6.

Oregon Climate Service. 2005. OCS website. Available from www. ocs.oregonstate.edu [accessed 23 September 2005].

Peck, E.L. 1972. Snow measurement predicament. Water Resour. Res. 8(1): 244-248. doi:10.1029/WR008i001p00244.

Robinson, A.C., and Rodda, J.C. 1969. Rain, wind and the aerodynamic characteristics of rain gauges. Met. Mag. 98: 113-120.

Schnorbus, M., and Alila, Y. 2004. Forest harvesting impacts on the peak flow regime in the Columbia Mountains of southeastern British Columbia: an investigation using long-term numerical modeling. Water Resour. Res. 40(5): W05205. doi:10.1029/ 2003WR002918.

Stevens, D., Jr., and Olsen, A. 2004. Spatially balanced sampling of natural resources. J. Am. Stat. Assoc. 99(465): 262-278. doi:10.1198/016214504000000250.

Storck, P., Lettenmaier, D., Connelly, B.A., and Cundy, T.W. 1995. Implications of forest practices on downstream flooding. Phase II final report. Washington Forest Protection Association, Olympia, Wash..

Storck, P., Kern, T., and Bolton, S. 1997. Measurement differences in snow accumulation, melt and micrometeorology between clear-cut and mature forest stands. In Proceedings of the Wes- tern Snow Conference, 4-8 May 1997, Banff, Alberta. Colorado State University, Fort Collins, Co.

Storck, P., Bowling, L., Wetherbee, P., and Lettenmaier, D. 1998. Application of GIS-based distributed hydrology model for prediction of forest harvest effects on peak streamflows in the Pacific Northwest. Hydrol. Process. 12(6): 889-904. doi:10.1002/ (SICI)1099-1085(199805)12:6<889::AID-HYP661>3.0.CO;2-P.

Surfleet, C. 2008. Uncertainty in forest road hydrologic modeling and catchment scale assessment of forest road sediment yield. Ph.D. dissertation, Oregon State University, Corvallis, Ore.

Toman, E. 2004. Forest road hydrology: the influence of forest roads on stream flow at stream crossings. M.Sc. thesis, Oregon State University, Corvallis, Ore.

Warrick, A.W., and Nielsen, D.R. 1980. Spatial variability of soil physical properties in the field. In Applications of soil physics. Edited by D. Hillel. Academic Press, New York. pp. 319-344.

Wemple, B.C. 1998. Investigations of runoff and sediment production from forest roads in western Oregon. Ph.D. dissertation, Oregon State University, Corvallis, Ore.

Wemple, B.C., and Jones, J.A. 2003. Runoff production on forest roads in a steep, mountain catchment. Water Resour. Res. 39(8): 1220-1237. doi:10.1029/2002WR001744.

Wemple, B., Jones, J., and Grant, G. 1996. Channel network extension by logging roads in two basins, western Cascades, Oregon. Water Resour. Bull. 32(6): 1195-1207.

Westrick, K. 1999. Soil depth calculation "aml" [online]. Available from www.hydro.washington.edu/Lettenmaier/Models/ DHSVM/index.shtml [accessed January 2005].

Whitaker, A., Alila, Y., Beckers, J., and Toews, D. 2003. Application of the Distributed Hydrology Soil Vegetation Model to Redfish Creek, British Columbia: model evaluation using internal catchment data. Hydrol. Process. 17(2): 199-224. doi:10. 1002/hyp.1119.

Wigmosta, M.S., and Perkins, W.P. 2001. Simulating the impacts of road drainage in a distributed hydrologic model. In Influence of urban and forest land uses on the hydrologic-geomorphic responses of watersheds. Edited by M.S. Wigmosta and S.J. Burges. American Geophysical Union, Washington, D.C. pp. 127-143.

Wigmosta, M.S., Vail, L., and Lettenmaier, D.P. 1994. A distributed hydrology-vegetation model for complex terrain. Water Resour. Res. 30(6): 1665-1679. doi:10.1029/94WR00436. 